\author{
RALPH E. SMITH \\ Urban Institute \\ JEAN E. VANSKI \\ Urban Institute \\ CHARLES C. HOLT \\ Urban Institute
}

\title{
Recession and the Employment of Demographic Groups
}

RECENT INCREASES in the national unemployment rate and forecasts of higher rates throughout 1975 have brought unemployment back into competition with inflation as the major economic problem. Since the three-andone-half-year low set in October 1973, aggregate unemployment has increased by almost 1.9 million people, raising the overall unemployment rate to 6.5 percent in November 1974. The reported rate among teenagers has risen from the October 1973 low of 14 percent to more than 17 percent; the rate among blacks is almost 12 percent; and the rate for black teenagers is over 37 percent. Further increases in unemployment over the next year are widely forecast and there is a natural concern that the already depressed groups will be hit the hardest.

Note: This research was supported by the U.S. Department of Labor, Office of Manpower Research, under Grant No. 92-11-72-36, and by the National Science Foundation, and the Ford Foundation. The opinions expressed are those of the authors and do not necessarily represent the views of the Urban Institute or its sponsors. The authors wish to thank William J. Scanlon and Richard S. Toikka for their comments, Jacqueline Taylor for her research assistance, and Laura von Behren for her editorial assistance. 
In the policy debates over the appropriate fiscal and monetary restraint and on programs to assist the casualties of recession, it is important to identify the people who will be most harmed. Programs to ameliorate or offset the impacts of recession are often targeted at particular groups in the labor market. For example, extending unemployment compensation and supplying jobs for those whose payments are exhausted would do little for the unemployed under age 25 , since very few of them have the work history to meet the eligibility requirements.

In this paper we use a job search-turnover model of the labor market to estimate the impact of a recession in 1975 on sixteen demographic groups, delineated by age, race, and sex. ${ }^{1}$ Through simulation, the model provides conditional forecasts of the incidence of employment losses by demographic groups. ${ }^{2}$ Since members of the groups with the highest unemployment rates-youth, blacks, and women-often react to a loss of job opportunities by withdrawing from the labor market, it is essential to estimate the reduced labor force participation of each group, as well as its increase in unemployment.

The paper begins with a description of the labor market model on which our estimates are based. The main concern of the paper is the presentation and interpretation of the employment outlook for each demographic group under aggregate labor market assumptions corresponding roughly to the current unemployment rate and to the more pessimistic unemployment forecasts for 1975. The final section contains a discussion of some of the policy issues associated with our conditional forecasts.

\section{Job Search-Turnover Model of the Labor Market}

This section describes the model we are using to simulate the labor market experiences of each demographic group. Although "unemployment" and "labor force participation" have been commonly associated with particular groups of people, the job search-turnover theory of the labor market associates these terms more accurately with states through

1. Ages $16-19,20-24,25-59$, and 60 and over for white and nonwhite (used interchangeably with "black" in this paper) males and females.

2. The model is described in Ralph E. Smith, "A Simulation Model of the Demographic Composition of Employment, Unemployment, and Labor Force Participation: Status Report," Working Paper 350-65 (Urban Institute, 1974; processed). 
which people pass dynamically. For example, the number of people unemployed at any one time depends on the flow of people into that state and the rapidity with which they leave it. Thus, a structural explanation of the determinants of the number of persons employed, unemployed, and in the labor stock requires structural descriptions of the processes that regulate the flows.

The numbers of people and jobs in various states influence the probabilities that transitions will occur between those states. These probabilities govern the flows that, in turn, change the sizes of the stocks. Our model of the labor market attempts to reflect this microdynamic structure for each of sixteen demographic groups. Demographic segmentation has been stressed because the variations among such groups have been found empirically to be important. Of course, age, race, and sex serve as proxies for a wide variety of differences in human capital and behavior that may not be inherently demographic in character.

\section{MODEL STRUCTURE}

The model structure is shown in Table 1. The exogenous variables are the aggregate job stock (employment plus job vacancies), the population of each group, and time. Total demand for labor is reflected in the aggregate job stock because measures of the job vacancies available to each demographic group do not exist. Within the model each group responds differently to variations in the aggregate stocks. Trend terms serve as proxies for long-term influences on labor market behavior not explicitly included in the model.

For each age-race-sex group, the expected monthly flow from one labor force stock to another is the product of a transition probability, depicted in brackets, and the size of the stock from which the flow originates. Equations (1) through (5) are of this type. In each equation the transition probability is expressed as a multiplicative function of the aggregate vacancyunemployment ratio, lagged one month, and an exponential time trend.

Our index of labor market tightness is the aggregate vacancy-unemployment ratio, whose size is an indicator of the availability of jobs in relation to the availability of people to fill them. For some of the flows the influence of this ratio is strong. For example, the flow from unemployment to employment, shown in equation (1), is positively related to the vacancyunemployment ratio for all groups. The impact of job availability on other 


\section{Table 1. Structure of the Job Search-Turnover Model Used to Simulate Labor Market Experiences in a 1975 Recession, by Age, Race, and Sex Group}

Equation number, type, and description Equation ${ }^{\mathrm{a}}$

For age-race-sex group $^{\mathrm{b}}$

(1) Flow from unemployment to employment

(2) Flow from employment to unemployment

(3) Flow from employment to not in the labor force

(4) Flow from unemployment to not in the labor force

(5) Flow from not in the labor force to labor force

(6) Probability of successful labor force entry

(7) Flow from not in the labor force to employment

(8) Flow from not in the labor force to unemployment

(9) Employment

(10) Unemployment

(11) Not in the labor force

For aggregate economic conditions

(177) Employment

$$
\begin{aligned}
& U E_{i}=\left[\alpha_{1 i}(V / U)_{-1}^{\beta_{1 i}} e^{\gamma_{1 i} T}\right] U_{i,-1} \\
& E U_{i}=\left[\alpha_{2 i}(V / U)_{-1}^{\beta_{2 i}} e^{\gamma_{2 i} T}\right] E_{i,-1}
\end{aligned}
$$

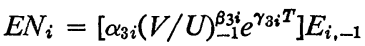

$$
\begin{aligned}
& U N_{i}=\left[\alpha_{4 i}(V / U)_{-1}^{\beta 4 i} e^{\gamma_{4 i} T}\right] U_{i,-1} \\
& N L_{i}=\left[\alpha_{5 i}(V / U)_{-1}^{\beta 5 i} e^{\gamma_{5 i} T}\right] N_{i,-1} \\
& (N E / N L)_{i}=\left[\alpha_{6 i}(V / U)_{-1}^{\beta_{6 i}} e^{\gamma_{6 i} T}\right] \\
& N E_{i}=(N E / N L)_{i} N L_{i} \\
& N U_{i}=N L_{i}-N E_{i} \\
& E_{i}=\left(E_{i,-1}+N E_{i}+U E_{i}\right. \\
& \left.-E N_{i}-E U_{i}\right)\left(\bar{P}_{i} / \bar{P}_{i,-1}\right) \\
& U_{i}=\left(U_{i,-1}+N U_{i}+E U_{i}\right. \\
& \text { - UN } \left.N_{i}-U E_{i}\right)\left(\bar{P}_{i} / \bar{P}_{i,-1}\right) \\
& N_{i}=\left(N_{i,-1}+U N_{i}+E N_{i}\right. \\
& \left.-N U_{i}-N E_{i}\right)\left(\bar{P}_{i} / \bar{P}_{i,-1}\right) \\
& E=\sum_{i} E_{i} \\
& U=\sum_{i} U_{i} \\
& V=\bar{J}-E
\end{aligned}
$$

(179) Vacancies

Source: Urban Institute, job search-turnover model of the labor market discussed in the text.

a. In equations (1)-(6), $\alpha, \beta$, and $\gamma$ are parameters from estimated behavioral relationships. The variable $T$ is the time trend. The subscript $i$ designates the respective age-race-sex groups. The term within the brackets depicts a transition probability. In equations (9)-(11) the $\bar{P}_{i}$ represent exogenous cohort population. In equation (179) $\bar{J}$ represents exogenous job stock, which is the sum of aggregate employment and vacancies.

b. Equations (1)-(11) are constructed for each of sixteen age-race-sex groups: ages 16-19, 20-24, $25-59$. 60 and over; white and nonwhite; males and females.

transitions, such as the flow of people into the labor force, shown in equation (5), is mixed. Market tightness encourages some potential new entrants and reentrants and may allow others to stay out of the labor force because members of their families are able to find work. The model does not include wages or prices as independent influences on labor market behavior, al- 
though they are, to some extent, reflected in the vacancy-unemployment ratio. The structure of relative wages changes slowly, so their omission may not seriously affect the prediction of short-term variations in labor force behavior. ${ }^{3}$ Instead, we assume that the cyclical ability of firms to fill vacancies is largely influenced by the availability of people and the competition of other employers. The success of job seekers is determined similarly. The duration of market search will influence workers' aspirations and participation decisions and employers' hiring standards.

A slightly different approach is taken in the model for estimating the flows from outside the labor force. First, each month individuals decide whether to enter the labor force, influenced by their own needs but also by market conditions. Equation (5) depicts this process. However, whether new entrants are successful in finding jobs is a joint decision of the entrants and potential employers. The tighter the labor market, the higher is the proportion of entrants who will have found jobs before the monthly survey, and, hence, who will not be observed as unemployed. Equation (6) represents the probability of successful entry, and equations (7) and (8) generate the expected flows into employment and unemployment from the flow into the labor force and the probability of being employed.

\section{MODEL ESTIMATES}

Our transition probability estimates are discussed elsewhere and will only be summarized here. ${ }^{4}$ Differences between demographic groups will be treated in the presentation of our forecasts below. A least-squares regression of the log form of each probability relation was estimated, using monthly data from July 1967 through December 1973. ${ }^{5}$ The results gener-

3. An extension of the model is planned, which will include wages and prices.

4. Smith, "Simulation Model."

5. Three sets of data are used and are described in ibid. Data on labor force status, by demographic group, are from tabulations from the Current Population Survey, provided by the U.S. Bureau of Labor Statistics. Flows between labor force categories are from unpublished tabulations of gross change from the CPS. The flows depict reported changes in classification between the reference weeks of one month and the next. Sampling and response problems with these data make them less reliable than the data on stocks and we have had to adjust the flow data to assure consistency. The transition probabilities reported in this paper are based on data that were adjusted prior to estimation of the transition relations. Our vacancy data are from the Conference Board's help-wanted index, published regularly in the Board's Statistical Bulletin, which we have scaled up to a level of vacancies consistent with some survey data (see note 14, below). All transition equations were estimated using seasonally unadjusted data with seasonal dummies. 
ally have the theoretically expected signs, reasonable consistency across demographic groups, and, for the larger groups, high statistical significance. For most groups the probability of unemployed members finding jobs each month-equation (1)-is directly related to labor market tightness, as reflected in the lagged vacancy-unemployment ratio; the probability of becoming unemployed-equation (2)-is inversely related to market tightness.

For most demographic groups the probability of leaving the labor force -equations (3) and (4)-is lower when unemployment is widespread and vacancies are few than in a tight labor market. Elsewhere we have presented possible explanations of this behavior. ${ }^{6}$ In spite of the fluctuations in these exit rates, the average probability of leaving the labor force is higher in periods of high unemployment, because unemployed people are so much more likely to drop out of the labor force than employed people are. ${ }^{7}$ This is sufficient to generate the cyclical fluctuations in labor force participation known as the discouraged-worker effect.

Estimates of equations (5) and (6) indicate that, for most groups, the probability of entering the labor force each month is not significantly affected by market conditions. However, the chances of a new entrant finding a job in his first month bear a strong direct relation to the vacancyunemployment ratio.

Equations (9) through (11) update the numbers in each group who are employed, unemployed, and out of the labor force by adding to the preceding month's level the predicted gross flows into the stock and subtracting the outflows. For each demographic group these stocks are then adjusted for the monthly changes in population.

The first eleven equations are estimated for each of the sixteen demographic groups, resulting in one hundred seventy-six equations. The model is then closed with three equations that aggregate the predicted employment and unemployment levels for the current period and generate the vacancy level by subtracting endogenous employment from the exogenous job stock.

6. Ralph E. Smith, "The Discouraged Worker in a Full Employment Economy," in American Statistical Association, 1973 Proceedings of the Business and Economic Statistics Section (1974), pp. 210-25.

7. Within each demographic group the average dropout rate among unemployed participants in the period July 1967 through June 1972 was at least double that of employed participants; for prime-age white males it was fourteen times as high and for prime-age white females it was six times as high. See ibid., p. 211. 


\section{TESTS OF THE MODEL}

The model can be solved recursively, since each month's flows depend on the preceding month's stocks, which are generated within the model. To make a simulation run with the model we assign initial values to all stocks and provide time series data on the exogenous job stock and the population levels.

As a test, the model was run monthly endogenously over a five-year sample period, ending in mid-1972, using estimated transition probability relations over the same period. The model tracked the historical values of aggregate employment, unemployment, and nonparticipation with considerable precision: the average absolute discrepancy between the estimates for employment from the Current Population Survey and from the model was 0.2 percent; for unemployment, 5.8 percent (about 230,000); and for nonparticipation, 0.6 percent. For each of the sixteen demographic groups, the average absolute percentage discrepancies for unemployment ranged from 6 percent for white females age 25-59, to 35 percent for black females over 60 . The discrepancies varied inversely with the sizes of the groups, reflecting sampling errors both in the model and in the CPS. ${ }^{8}$ There seems to be no systematic bias or error accumulation.

Subsequent simulations tested the ability of the model to forecast beyond the sample period and found prediction errors of similar magnitudes. Its performance in predicting aggregate employment and unemployment was, in fact, slightly better in the two years beyond the sample period, but the discrepancies for individual demographic groups were somewhat larger.

To obtain the most relevant estimates for the current study, we reestimated the equations using data through December 1973, with small changes in the parameter estimates. ${ }^{9}$ Through the first nine months of 1974 , the absolute magnitudes of the prediction errors have remained the same. From March until September the level of unemployment was systematically overestimated by about 0.3 to 0.4 percentage point, but by September the gap

8. Since the random sampling errors of the CPS are higher for the smaller demographic groups, the regression errors in estimates of their transition-probability functions are also higher.

9. An appendix containing the revised estimates is available from the authors on request. Time has not permitted a full study of the prediction errors of the simulation model, but a second appendix is available, which gives the prediction errors outside the sample period for all demographic groups. 
was closed. Our model predicted a gradual rise in unemployment throughout those months, rather than the sharp increase in September reported by the CPS.

\section{Forecasts of Employment for Demographic Groups}

To forecast labor market conditions for each demographic group in 1975 , the model requires data on its civilian noninstitutional population and predictions of the aggregate job stock. The former were derived from unpublished estimates for July 1 of 1975 and 1976, provided by the Bureau of the Census. ${ }^{10}$

Two alternative economic scenarios for 1975 are analyzed in terms of their impacts on the labor market. Each is driven by an assumed growth or decay in the aggregate seasonally adjusted job stock. ${ }^{11}$ In each run the starting values of the group employment, unemployment, and nonparticipation levels are the simulated values for October 1974, which are very close to those observed by the CPS. ${ }^{12}$

The "current unemployment" simulation provides a slow expansion in job opportunities, from 88.6 million in October 1974 to 90.6 million in December 1975, to maintain an average unemployment rate of about 6 percent for 1975, the level of October 1974. This outcome is more optimistic than most economists, both in and out of government, believe likely, and serves as a basis for estimating the increased levels of unemployment now being forecast.

The "high unemployment" simulation posits a steady deterioration in job opportunities throughout 1975 , sufficient to reduce the job level to 87.1 million and to raise the unemployment rate to 8.1 percent by December. The result would be an average unemployment rate for the year of 7.2 percent, the highest since 1941 and the rate typical of current pessimistic forecasts.

10. We are grateful to Campbell Gibson and Robert Warren of the Population Division for these estimates. We estimated monthly levels by assuming constant growth rates between these two dates.

11. Seasonal dummies have been dropped from the behavioral relations, so the simulation model yields seasonally adjusted estimates.

12. Simulated, rather than historical, values were used for initial conditions because BLS does not regularly publish seasonally adjusted data for the sixteen demographic groups. 
In the following section, we also examine equilibrium levels and the dynamics of labor market adjustment to changes in the aggregate job stock. Our observations suggest what to anticipate if 1975 differs from our simulations in the degree of the recession or in the time path of the job losses.

\section{OVERALL IMPACT OF A RECESSION}

Compared with the group's prospects if the unemployment rate remains at around 6 percent, the most visible and probably the most dramatic aspect of a steadily deteriorating job market is the effect the high unemployment scenario would have on each group's unemployment rate.

Every major demographic group would suffer deeper unemployment, according to the simulation. Those with the highest initial unemployment rates would suffer the most. By December 1975, black teenagers and black male adults would experience increases of 7 and 3 percentage points, respectively, while the unemployment rate of adult white males would rise by only 2.5 points. However, the relative positions of blacks and teenagers show some improvement. The ratio of black to white unemployment rates declines from 1.9 to 1.7, and that of teenagers to adults from 3.1 to 2.9. The share of white male adults in total unemployment increases from 33 to 39 percent; and the share of teenagers declines from 26 to 23 percent.

In addition to its impact on the unemployment rates of demographic groups, a recession is associated with reduced labor force participation. ${ }^{13}$ Women, youth, and blacks are particularly likely to react to a reduction in job opportunities by dropping out of the labor force. Since white male adults are the only large demographic group whose participation rate is cyclically insensitive, their share of the employment loss during a recession would be overstated by focusing only on unemployment shares. Also, simple comparisons between current labor force participation rates and those forecast for 1975 would understate the discouragement of women, since there are strong positive trends in their participation rates on the order of 1.5 percent per year, ceteris paribus.

To examine the impact of the recession on employment, unemployment, and labor force in 1975, we have prepared annual averages under the high unemployment and current unemployment scenarios. These are provided

13. For a survey of this extensive literature, see Herbert Parnes, "Labor Force Participation and Labor Mobility," in Industrial Relations Research Association Series, $A$ Review of Industrial Relations Research, Vol. 1 (University of Wisconsin, IRRA, 1970). 
Table 2. Aggregate Impact of a Job Reduction in 1975, by Labor Market Indicator, under Alternative Assumptions

Annual averages in thousands, except as indicated

\begin{tabular}{lcrr}
\hline Labor market indicator & $\begin{array}{c}\text { Current- } \\
\text { unemployment } \\
\text { assumption }\end{array}$ & Impact & $\begin{array}{c}\text { High- } \\
\text { unemployment } \\
\text { assumption }\end{array}$ \\
\hline Jobs & 89,866 & $-2,217$ & 87,649 \\
Vacancies & 2,329 & -770 & 1,559 \\
Labor force & 93,093 & -304 & 92,789 \\
Employment & 87,537 & $-1,447$ & 86,090 \\
Unemployment & 5,556 & 1,143 & 6,699 \\
Unemployment rate (percent) & 6.0 & 1.2 & 7.2 \\
\hline
\end{tabular}

Sources: Derived from equations in Table 1. The sources of the basic data are given in text note 5 above.

in Table 2. The difference in average levels of available jobs is about 2.2 million. Note that the difference in employment is smaller. A contraction in available jobs not only reduces employment, but also reduces unfilled vacancies, which we estimate would be about one-third lower. ${ }^{14}$

The forecast summarized in this table indicates that an employment reduction of $1,447,000$ is associated with an increase in unemployment of $1,143,000$, and a reduction in the labor force of 304,000 . Thus, in this situation, about four-fifths of the employment impact would be reflected in unemployment. The drop in labor force participation is less than would be suggested by the literature on the discouraged worker. We attribute this difference primarily to the dynamic character of the labor force response to changes in job opportunities. Participation depends on the probability of entering the labor market, which is not sensitive to labor market conditions, and on the exit probability, which is sensitive because it is directly influenced by the number of people who are unemployed. Thus, the most important determinant of the cyclical variation in participation rates is the large probability of dropping out of the labor force once unemployed com-

14. In the absence of comprehensive vacancy data, we have used the cyclical variation in the Conference Board's help-wanted index to estimate the transition relationships. To create an aggregate job-stock series, we scaled the index to correspond to an average vacancy level in the sample period of about 2 million. This is over twice the level estimated by BLS during the short period (1969-73) over which they surveyed employers; see Employment and Earnings, Vol. 20 (March 1974), p. 123. However, we believe their estimate is biased downward; see William J. Scanlon and Charles C. Holt, "Demand for Labor in a Dynamic Theory of the Firm," Working Paper 350-68 (Urban Institute, 1974; processed), Appendix B. 
pared with the exit probability while employed. As the proportion of the labor force without jobs builds, the dropout rate should rise, and, hence, the fall in participation should follow. For example, the current probability of prime-age white females (25-59) dropping out of the labor force is about 4 percent per month if employed and 35 percent if unemployed; a 4.6 percent unemployment rate thus implies an average exit rate of 5.4 percent per month. ${ }^{15}$ If their unemployment rate rose to 5.25 percent in December 1975 , as predicted under the high-unemployment scenario, then their average probability of leaving the labor force would rise to 5.8 percent per month. ${ }^{16}$ About three-fifths of this increase in the exit rate is due to the shift of women from employment into the exit-prone unemployment stock. ${ }^{17}$ Even after the exit probability has risen in response to deepening unemployment, some time will be required for their labor force participation to respond fully.

The two simulations differ not only in their average job levels, but also in their state of flux. Throughout the year, the unemployment rate in one is increasing rapidly; hence, the full impact of the discouraged-worker effect is not yet reflected in the size of its labor force. Examination of the monthly differences in the sizes of the labor force in the two simulations supports this hypothesis. Later in the paper we analyze more fully the dynamic and steady-state implications of the model; suffice it to say here that the reduction in participation is smaller when unemployment is rising than when it is falling.

\section{COMPOSITION OF THE IMPACT}

The sizes of the demographic impacts of a slacker labor market are shown in Table 3, which provides the 1975 annual averages of employment, unemployment, and participation of each demographic group under the two

15. That is, $(.04 \times 95.4)+(.35 \times 4.6)=5.43$.

16. The probability of an employed female dropping out of the labor force declines to 0.0353 and the probability of an unemployed female dropping out rises to 0.462 .

17. If transition probabilities within each stock were constant, then the shift within the labor force of prime-age white women out of employment into unemployment would have generated a total exit rate of 5.63 percent; that is, $(.04 \times 94.75)+(.35 \times 5.25)=$ 5.63. The transition probabilities presented here are based on equations that were estimated with gross flow data adjusted for inconsistencies between them and the CPS data on labor force status. 
Table 3. Impact on Labor Force Status of a Job Reduction in 1975, by Demographic Group, under Alternative Assumptions

Annual averages in thousands, except as indicated

\begin{tabular}{|c|c|c|c|c|c|c|}
\hline $\begin{array}{c}\text { Age group } \\
\text { and } \\
\text { labor market } \\
\text { indicator }\end{array}$ & $\begin{array}{l}\text { Current- } \\
\text { unem- } \\
\text { ployment } \\
\text { assump- } \\
\text { tion }\end{array}$ & Impact & $\begin{array}{l}\text { High- } \\
\text { unem- } \\
\text { ployment } \\
\text { assump- } \\
\text { tion }\end{array}$ & $\begin{array}{l}\text { Current- } \\
\text { unem- } \\
\text { ployment } \\
\text { assump- } \\
\text { tion }\end{array}$ & Impact & $\begin{array}{l}\text { High- } \\
\text { unem- } \\
\text { ployment } \\
\text { assump- } \\
\text { tion }\end{array}$ \\
\hline & \multicolumn{6}{|c|}{ WHITE } \\
\hline & & Males & & & Females & \\
\hline \multicolumn{7}{|l|}{$16-19$} \\
\hline Labor force & 4,548 & -15 & 4,534 & 3,729 & -46 & 3,683 \\
\hline Employment & 3,902 & -113 & 3,789 & 3,211 & -110 & 3,101 \\
\hline Unemployment & 646 & 99 & 745 & 518 & 64 & 582 \\
\hline $\begin{array}{l}\text { Unemployment } \\
\text { rate (percent) }\end{array}$ & 14.2 & 2.2 & 16.4 & 13.9 & 1.9 & 15.8 \\
\hline $\begin{array}{l}\text { Participation } \\
\quad \text { rate (percent) }\end{array}$ & 66.0 & -0.2 & 65.8 & 53.5 & -0.7 & 52.8 \\
\hline \multicolumn{7}{|l|}{$20-24$} \\
\hline Labor force & 6,547 & -19 & 6,528 & 5,253 & -31 & 5,223 \\
\hline Employment & 5,962 & -192 & 5,770 & 4,819 & -115 & 4,704 \\
\hline Unemployment & 585 & 173 & 759 & 435 & 84 & 519 \\
\hline $\begin{array}{l}\text { Unemployment } \\
\text { rate (percent) }\end{array}$ & 8.9 & 2.7 & 11.6 & 8.3 & 1.6 & 9.9 \\
\hline $\begin{array}{l}\text { Participation } \\
\quad \text { rate (percent) }\end{array}$ & 86.4 & -0.2 & 86.2 & 64.8 & -0.4 & 64.4 \\
\hline \multicolumn{7}{|l|}{$25-59$} \\
\hline Labor force & 34,663 & 51 & 34,714 & 20,777 & -265 & 20,512 \\
\hline Employment & 33,617 & -360 & 33,257 & 19,831 & -350 & 19,481 \\
\hline Unemployment & 1,046 & 411 & 1,458 & 947 & 85 & 1,031 \\
\hline $\begin{array}{l}\text { Unemployment } \\
\text { rate (percent) }\end{array}$ & 3.0 & 1.2 & 4.2 & 4.6 & 0.4 & 5.0 \\
\hline $\begin{array}{l}\text { Participation } \\
\text { rate (percent) }\end{array}$ & 93.6 & 0.1 & 93.7 & 52.9 & -0.6 & 52.3 \\
\hline \multicolumn{7}{|l|}{60 and over } \\
\hline Labor force & 4,400 & 50 & 4,450 & 2,510 & 36 & 2,547 \\
\hline Employment & 4,196 & 13 & 4,209 & 2,425 & -6 & 2,419 \\
\hline Unemployment & 204 & 37 & 241 & 86 & 42 & 128 \\
\hline $\begin{array}{l}\text { Unemployment } \\
\text { rate (percent) }\end{array}$ & 4.6 & 0.8 & 5.4 & 3.4 & 1.6 & 5.0 \\
\hline $\begin{array}{l}\text { Participation } \\
\quad \text { rate (percent) }\end{array}$ & 37.4 & 0.4 & 37.8 & 15.9 & 0.2 & 16.1 \\
\hline
\end{tabular}


Table 3 (continued)

\begin{tabular}{|c|c|c|c|c|c|c|}
\hline $\begin{array}{l}\text { Age group } \\
\text { and } \\
\text { labor market } \\
\text { indicator }\end{array}$ & $\begin{array}{l}\text { Current- } \\
\text { unem- } \\
\text { ployment } \\
\text { assump- } \\
\text { tion }\end{array}$ & Impact & $\begin{array}{l}\text { High- } \\
\text { unem- } \\
\text { ployment } \\
\text { assump- } \\
\text { tion }\end{array}$ & $\begin{array}{l}\text { Current- } \\
\text { unem- } \\
\text { ployment } \\
\text { assump- } \\
\text { tion }\end{array}$ & Impact & $\begin{array}{l}\text { High- } \\
\text { unem- } \\
\text { ployment } \\
\text { assump- } \\
\text { tion }\end{array}$ \\
\hline & \multicolumn{6}{|c|}{ NONWHITE } \\
\hline & & Males & & & Females & \\
\hline \multicolumn{7}{|l|}{$16-19$} \\
\hline Labor force & 511 & -20 & 491 & 430 & -23 & 407 \\
\hline Employment & 366 & -43 & 324 & 291 & -28 & 263 \\
\hline Unemployment & 144 & 23 & 167 & 139 & 5 & 144 \\
\hline $\begin{array}{l}\text { Unemployment } \\
\text { rate (percent) }\end{array}$ & 28.3 & 5.7 & 34.0 & 32.3 & 3.1 & 35.4 \\
\hline $\begin{array}{l}\text { Participation } \\
\text { rate (percent) }\end{array}$ & 44.2 & -1.7 & 42.5 & 34.6 & -1.9 & 32.7 \\
\hline \multicolumn{7}{|l|}{$20-24$} \\
\hline Labor force & 886 & -4 & 882 & 823 & -17 & 805 \\
\hline Employment & 728 & -41 & 687 & 669 & -13 & 657 \\
\hline Unemployment & 158 & 37 & 195 & 154 & -5 & 149 \\
\hline $\begin{array}{l}\text { Unemployment } \\
\text { rate (percent) }\end{array}$ & 17.9 & 4.2 & 22.1 & 18.7 & -0.2 & 18.5 \\
\hline $\begin{array}{l}\text { Participation } \\
\quad \text { rate (percent) }\end{array}$ & 80.3 & -0.4 & 79.9 & 60.0 & -1.3 & 58.7 \\
\hline \multicolumn{7}{|l|}{$25-59$} \\
\hline Labor force & 3,969 & -15 & 3,954 & 3,290 & 4 & 3,294 \\
\hline Employment & 3,740 & -56 & 3,684 & 3,059 & -31 & 3,028 \\
\hline Unemployment & 230 & 40 & 270 & 231 & 35 & 266 \\
\hline $\begin{array}{l}\text { Unemployment } \\
\text { rate (percent) }\end{array}$ & 5.8 & 1.0 & 6.8 & 7.0 & 1.1 & 8.1 \\
\hline $\begin{array}{l}\text { Participation } \\
\text { rate (percent) }\end{array}$ & 88.5 & -0.4 & 88.1 & 59.5 & $*$ & 59.5 \\
\hline \multicolumn{7}{|l|}{60 and over } \\
\hline Labor force & 427 & 4 & 431 & 330 & 6 & 336 \\
\hline Employment & 404 & -8 & 396 & 320 & 4 & 324 \\
\hline Unemployment & 23 & 12 & 35 & 10 & 2 & 12 \\
\hline $\begin{array}{l}\text { Unemployment } \\
\text { rate (percent) }\end{array}$ & 5.5 & 2.6 & 8.1 & 3.1 & 0.6 & 3.7 \\
\hline $\begin{array}{l}\text { Participation } \\
\text { rate (percent) }\end{array}$ & 34.6 & 0.3 & 34.9 & 20.8 & 0.4 & 21.2 \\
\hline
\end{tabular}

Source: Same as Table 2. The calculations are made from data before rounding.

* Less than 0.05 . 
demand assumptions. The unemployment rate of virtually every group is predicted to increase under the high-unemployment condition, ${ }^{18}$ but the heaviest impact is felt among groups with unemployment rates that are already high: youth in general and black male teenagers in particular. Of the major groups prime-age white females appear to be least affected by the unemployment increases; their unemployment rate rises by only 0.4 point, while the aggregate rate, and the rate among prime-age white males, increases by 1.2 percentage points.

With two minor exceptions, the employment levels of every group are adversely affected by a reduction in available jobs, reflecting the combined impact of labor force and unemployment responses. ${ }^{19}$ The impact of fewer jobs on labor force participation varies considerably among groups. The size of the labor force and the corresponding participation rate of primeage white males and black females and of people age 60 and over increase by small amounts. Participation rates of all other groups decline, with black teenagers and black women 20-24 most severely discouraged.

Table 4 demonstrates the differences across groups in the severity of the impact under the high-unemployment scenario as compared with the current-unemployment assumption. The first column, which reports the percentage reduction in the group's employment level, makes clear that youth are particularly hard hit by the recession and adult white women are more severely affected than adult white men. A 1.6 percent reduction in aggregate employment in 1975 is expected to reduce the employment of black teenagers by more than 10 percent, of prime-age white women by 1.8 percent, and of prime-age white men by only 1.1 percent.

The second and third columns of Table 4 reveal that, while in the aggregate, four-fifths of the employment loss is reflected in increased unemployment, only one-fourth of the job losses of prime-age white women and an even smaller proportion of losses by young black females show up in their unemployment. Other youth and prime-age black males also have large labor force losses. This, of course, is another way of viewing the difference in the participation rate reactions reported in Table 3. Tabulating the impacts in this fashion makes it more apparent that focusing on unemploy-

18. The single exception is the group of black females, age 20-24, whose rate is predicted to decline by 0.2 point; however, the transition-probability equations for this group have very low explanatory power.

19. The two exceptions are white males, age 60 and over, and black females, age 60 and over. 
Table 4. Severity of Employment Losses from a Job Reduction in 1975, by Demographic Group

1975 impacts of high unemployment as a percentage of current employment

\begin{tabular}{lccc}
\hline Color-sex-age group & $\begin{array}{c}\text { Impact on } \\
\text { employment }\end{array}$ & $\begin{array}{c}\text { Impact on } \\
\text { unemployment }\end{array}$ & $\begin{array}{c}\text { Impact on } \\
\text { labor force }\end{array}$ \\
\hline Aggregate & -1.65 & 1.30 & -0.35 \\
White males & -2.90 & & \\
$16-19$ & -3.22 & 2.54 & -0.38 \\
$20-24$ & -1.07 & 1.90 & -0.32 \\
$25-59$ & 0.31 & 0.88 & 0.15 \\
60 and over & & & 1.19 \\
White females & -3.43 & 1.99 & \\
$16-19$ & -2.39 & 1.74 & -1.43 \\
$20-24$ & -1.76 & 0.43 & -1.34 \\
$25-59$ & -0.24 & 1.73 & 1.48 \\
60 and over & & & \\
Nonwhite males & -11.75 & 6.28 & -5.46 \\
$16-19$ & -5.63 & 5.08 & -0.55 \\
$20-24$ & -1.50 & 1.07 & -0.40 \\
$25-59$ & -1.98 & 2.97 & 0.99 \\
60 and over & & & \\
Nonwhite females & -9.62 & 1.72 & -7.90 \\
$16-19$ & -1.94 & -0.75 & -2.54 \\
$20-24$ & -1.01 & 1.14 & 0.13 \\
$25-59$ & 1.25 & 0.63 & 1.87 \\
60 and over & & &
\end{tabular}

Source: Calculated from data in Table 3, before rounding; each impact is calculated as a percent of that group's 1975 current-unemployment employment level.

ment not only understates the job losses in a recession but also distorts the perception of the groups who suffer the worst losses.

The hypothesized job loss, as reported above, reduces employment by 1.4 million. Although this is too small a fraction to induce major changes in employment, the uneven demographic incidence of job losses and the participation reactions are dramatic. Table 5 gives the shares of employment and unemployment of several major demographic groups under the current-unemployment assumption, and compares them with their shares resulting from fewer job opportunities.

White males incur a disproportionate share of measured unemployment increases, compared with their previous unemployment share (compare columns 4 and 5); yet, because they do not alter their participation rate 
Table 5. Impact of a Job Reduction in 1975 on Shares of Employment and Unemployment, by Demographic Group, under Alternative Assumptions

Annual average in percent

\begin{tabular}{|c|c|c|c|c|c|c|}
\hline \multirow[b]{2}{*}{$\begin{array}{l}\text { Color-sex, and } \\
\text { age group }\end{array}$} & \multicolumn{3}{|c|}{$\begin{array}{c}\text { Impact on employment } \\
\text { shares }\end{array}$} & \multicolumn{3}{|c|}{$\begin{array}{c}\text { Impact on unemployment } \\
\text { shares }\end{array}$} \\
\hline & $\begin{array}{c}\text { Current } \\
\text { unem- } \\
\text { ployment } \\
(1)\end{array}$ & $\begin{array}{l}\text { Impact } \\
(2)\end{array}$ & $\begin{array}{c}\text { High } \\
\text { unem- } \\
\text { ployment } \\
(3)\end{array}$ & $\begin{array}{l}\text { Current } \\
\text { unem- } \\
\text { ployment } \\
(4)\end{array}$ & $\begin{array}{l}\text { Impact } \\
(5)\end{array}$ & $\begin{array}{c}\text { High } \\
\text { unem- } \\
\text { ployment } \\
(6)\end{array}$ \\
\hline \multicolumn{7}{|l|}{ Color and sex } \\
\hline White males & 54.5 & 45.1 & 54.6 & 44.6 & 62.9 & 47.8 \\
\hline White females & 34.7 & 40.1 & 34.5 & 35.6 & 24.0 & 33.7 \\
\hline Nonwhite males & 5.8 & 10.0 & 5.7 & 9.8 & 9.7 & 9.8 \\
\hline Nonwhite females & 5.0 & 4.6 & 5.0 & 9.6 & 3.3 & 8.6 \\
\hline Total & 100.0 & 100.0 & 100.0 & 100.0 & 100.0 & 100.0 \\
\hline \multicolumn{7}{|l|}{ Age } \\
\hline $16-24$ & 22.8 & 45.3 & 22.4 & 50.0 & 42.0 & 48.7 \\
\hline 25 and over & 77.2 & 54.7 & 77.6 & 50.0 & 58.1 & 51.4 \\
\hline Total & 100.0 & 100.0 & 100.0 & 100.0 & 100.0 & 100.0 \\
\hline
\end{tabular}

Source: Calculated from data in Table 3, using the aggregates in lines 4 and 5 of Table 2 as 100 percent for the respective columns. Calculations are made from data before rounding.

as job opportunities shift, their share of aggregate employment losses is much smaller than their share of employment (compare columns 1 and 2). The situation is reversed for white women. They suffer a small share of the total unemployment increases ( 24 percent, as reported in column 5) but a large proportion of employment losses (the 40.1 percent of column 2), again due to their labor force discouragement. Hence, we anticipate that a higher aggregate unemployment rate would reduce the ratio of female to male unemployment rates, but still make women relatively worse off in employment terms.

The situation for blacks and young workers reflects the same phenomenon. The ratio of black to white unemployment would decline with contracting availability of jobs, while blacks would lose much more than their average share of employment. Finally, young people would incur 45 percent of the total employment loss, almost double their current employment share, while experiencing a slight decline in their share of unemployment. 


\section{Labor Market Statics and Dynamics}

The foregoing simulation of the labor market is based on forecasts of rising unemployment. The 1975 average results that were presented, particularly with regard to participation, were found to depend on the rate at which the demand for labor deteriorated.

In order to explore more general properties of the model, one can determine what would happen if (1) the unemployment rate were allowed to reach a constant, indefinitely sustained level; and (2) if there were a onetime precipitate decline in jobs. To avoid confounding the picture with other issues, we will neglect trends in behavior or group size.

\section{CONSTANT UNEMPLOYMENT RATE}

The level at which unemployment is held constant is significant, so we simulate rates ranging from 4 to 8 percent, and plot the aggregate results predicted from the model in Figure 1. The constant unemployment rates are shown as vertical lines corresponding to different ratios of jobs to population shown on the bottom scale. The levels of exogenous jobs and the equilibrium labor force and employment responses are shown by the top three lines. The number of unemployed workers is indicated by the shaded areas between the labor force and employment lines, and similarly, vacancies by the area between the job and employment lines. At higher job levels both the labor force and employment are higher, but employment shows a diminishing response to increased vacancies as unemployment is squeezed and the supply of potential entrants declines.

At the bottom of the figure, the ratio of unfilled job vacancies to unemployed workers rises sharply at high ratios of available jobs to population. Since the vacancy-unemployment ratio $(V / U)$ is an index of inflationary pressure on wages, it reflects the ceiling on full employment that is imposed by inflation. However, since the inflation rate depends on price as well as wage dynamics, there remains doubt about the existence of a "natural" rate of unemployment that is an inherent frictional and structural characteristic of the stock-flow properties of the labor market alone. In the American economy, inflationary pressure becomes excessive long before $V / U$ approaches unity, the point that some advance as the ideal labor 
Figure 1. Effect on Future Labor Force, Jobs, Employment, and Vacancies, of Holding Alternative Unemployment Rates Constant from October 1974
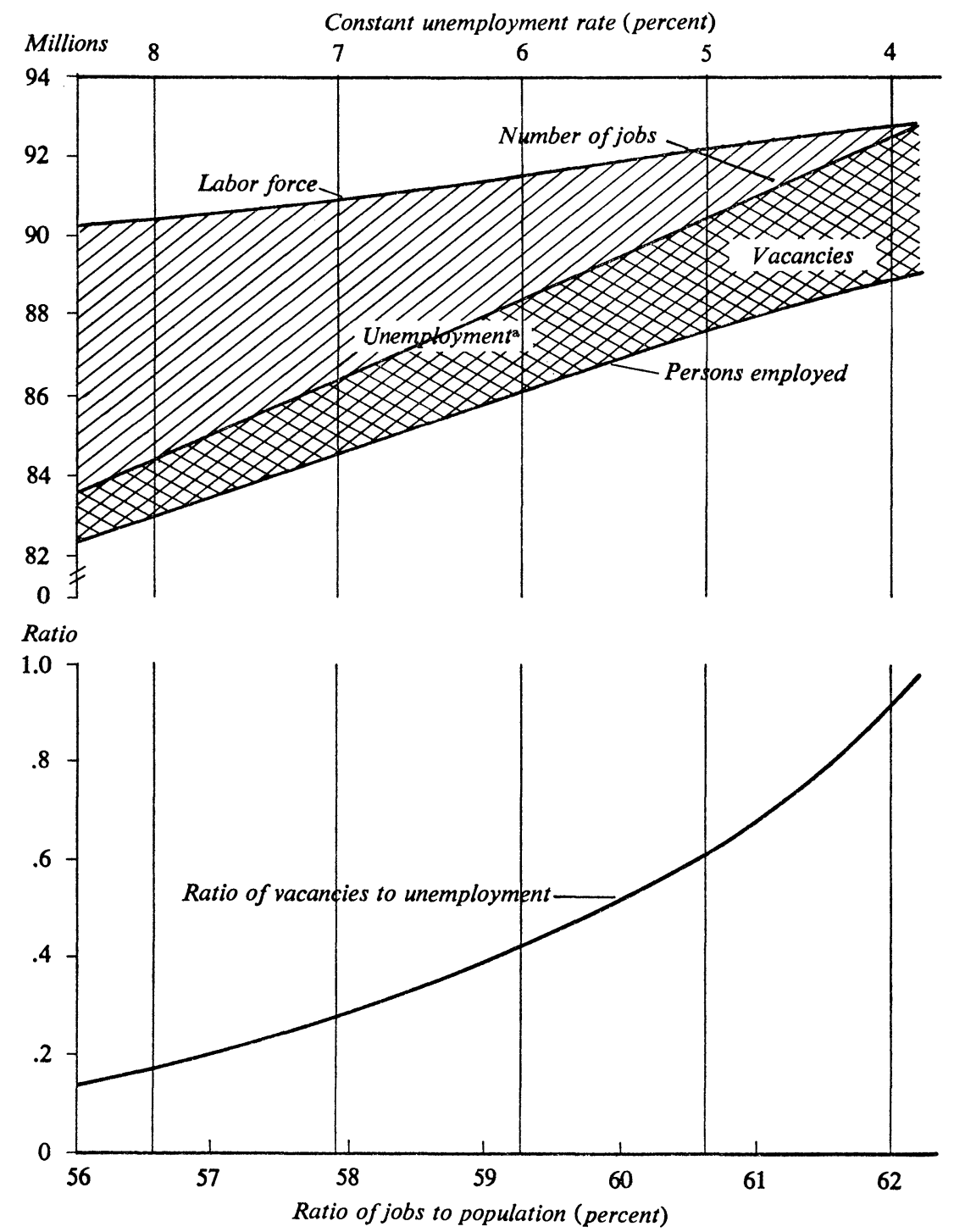

Source: Authors' labor market model, with the unemployment rate held constant from October 1974 at alternatives of $4,5,6,7$, and 8 percent.

a. The number of unemployed workers covers the shaded areas between the labor force and employment lines. 
market balance. The reason for the chronically low $V / U$ in the United States is far from clear. One explanation is that an employer can fill a vacancy by recruiting not only among the unemployed, but also among employed and discouraged workers. To induce an employed worker to change jobs is likely to require an inflationary wage increase, and the defense against such pirating is likely to be inflationary on-the-job wage increases. It may not take a large increase in vacancies to stimulate these atomistic wage processes which then impinge, with a lag, on wage agreements negotiated through collective bargaining.

Since labor constitutes over three-quarters of the aggregate factor input to economic production, substantial anti-inflationary pressure presumably is generated by raising unemployment relative to vacancies. This is a large part of the slack capacity that present policies aimed at restricting aggregate demand are designed to produce. Unfortunately, however, the convexity of $V / U$ suggests diminishing anti-inflationary returns to higher levels of unemployment, and the discouragement and unemployment that are created fall heavily on groups of workers who are at a relative disadvantage, as reflected in low wages and in high turnover and dropout rates.

We can now compare this analysis of constant unemployment rates to the foregoing simulation of steadily worsening labor demand in 1975 . When "high" unemployment of 7.2 percent was compared to "current" unemployment of 6.0 percent, we predicted that four-fifths of the reduction in employment showed up as unemployment. In the equilibrium case shown in Figure 1, only 63 percent of the employment decline appears in unemployment because the size of the labor force is fully adjusted to the depressed demand.

\section{RESPONSE TO A SUDDEN DECLINE IN JOBS}

To simulate the impact of demand change, the available job stock was suddenly reduced from equilibrium by 1 million positions in the labor market model. Vacancies drop immediately and unemployment gradually builds, as workers flow into unemployment while fewer workers are hired. The sharp reduction in new hires quickly reduces employment, which in turn allows the stock of vacancies to recover substantially. These changes take roughly four months. The increasing discouragement resulting from rising unemployment slowly erodes labor force participation, so that the labor force continues to fall for about eight months. These dropouts come 
largely from unemployment, so its initial overshoot is gradually reduced. In the case of a decline of 1 million available jobs, unemployment rises from 5.4 million to a peak of 6.0 million four months later, finally settling back to 5.9 million. ${ }^{20}$ Most of the adjustments have been completed within six months. ${ }^{21}$

\section{Policy Implications}

In this paper we have concentrated on the costs of moving from roughly the current level of unemployment to that corresponding to the most pessimistic scenario of rising unemployment. We have not tried to weigh these costs against the hoped-for reduction in inflation, and hence we are not attempting to evaluate the policies leading to the forecasts. Our results can be scaled down to reflect more optimistic forecasts, since the composition of impacts would be little changed, except for transitory effects.

Our simulations of alternative job outlooks for 1975 indicate that the groups who are competitively disadvantaged in the labor market would be hardest hit by the recession, just as they have been most affected by the job losses during the past year. However, the employment of every major demographic group suffers by a reduction in job opportunities. The impact on women is reflected not so much in their unemployment rates as in the retardation of their growing participation in the labor force. The highly visible losses in the unemployment rates of youth and blacks will be aggravated by largely invisible participation responses.

20. The scale factor used to estimate aggregate vacancies from the help-wanted index has very little impact on our static predictions, but does affect the speeds of adjustment. Since data for estimating this scale factor are weak, we note its effect on the dynamics of the labor market model. A higher scale factor corresponding to a higher estimate of vacancies results in a slower adjustment of employment and unemployment, and unemployment does not overshoot its new equilibrium. The participation response still lags unemployment. A lower vacancy scale factor increases the speed of adjustment.

21. The demographic compositions of the labor force and unemployment depend on the time path of the ratio of jobs to population. Although the model simulates these effects in detail, space does not permit their exploration here. Ratios between black and white unemployment rates, for example, should not be expected to be cyclically constant, even aside from changes in the industrial composition of employment. An occupational model, driven by industrial demand, would be needed to refine dynamic compositional impacts on the labor market. Wage responses are likely to be slower than the stock-flow processes that have been incorporated in the model. 
The explosive issue of the relative importance of jobs for women and youth versus those for adult males need not be fought out here. Regardless of one's position on this issue, the formulation of policies and programs to deal with the harmful results of lost job opportunities obviously should consider the special problems that each group confronts.

Today, about one-half of the unemployed are under age 25 . Our estimates indicate that increases in the aggregate unemployment rate would not significantly change this share. Most of the unemployed in this age group do not meet the work-history requirements for unemployment compensation. Their problems, in any event, involve losses not only of income, which may be small relative to those of older workers, but also of opportunities to develop work skills, to use their recently acquired knowledge, and in other ways to develop their potential. The adverse effects of these missed opportunities may persist in the form of difficulty in finding good jobs and in attitudes toward work..$^{22}$ Public employment programs or subsidies to private employers may ameliorate their problems, although neither is a substitute for a good job market.

The large numbers of women and blacks made jobless by a recession would also lose both current income and opportunities to develop skills and seniority. Compliance with requirements for equal employment opportunity becomes considerably more difficult as total job opportunities decline. Courts have, in fact, already had to grapple with the recession-induced issue of whether recently hired women and minorities are subject to the traditional seniority rules for layoffs. If our estimates of their shares of employment losses are correct-white women accounting for 40 percent and blacks for 15 percent-the issue of who gets the remaining jobs will become increasingly troublesome.

Our estimates also indicate that the macroeconomic problem of stimulating the economy to reduce unemployment will become somewhat more difficult as the recession is prolonged. The reason for this is the accumulation of potential workers outside the labor force who will search for and take jobs as employment opportunities expand. These hidden unemployed have only temporarily withdrawn from the labor market. As they return,

22. For evidence that past failure in the labor market may influence subsequent labor force participation decisions, see Stuart O. Schweitzer and Ralph E. Smith, "The Persistence of the Discouraged Worker Effect," Industrial and Labor Relations Review, Vol. 27 (January 1974), pp. 249-60. 
they will compete for jobs and will retard the decline in reported unemployment.

The individuals who will suffer the greatest loss of employment as the result of the fight against inflation are those who bear all the handicaps that, in a demographic model, are reflected in being young, black, and female. The demographic handicaps may, in finer analysis, translate into lack of education, labor market knowledge, job skills, and seniority; conflicts between home and work roles; and discrimination. While a purely demographic model cannot analyze these causes, it does allow observation of significant behavioral differences associated with age, race, and sex, and their interactions.

To the extent that this demographic model accurately reflects the structure of the American labor market, it reveals serious structural problems and inequities. Even under "normal" conditions, they account for excessively high rates of unemployment and discouragement from participation. But these unsolved and largely untreated structural problems are seriously aggravated by the intentional creation of slack capacity to fight inflation.

Our simulation model has been used here primarily to study unemployment and participation in the labor market, but it could be used to study the impacts of changing the behavioral probability of particular demographic groups relating to labor market entry, hiring, layoffs, quits, withdrawals, and retirements. Many government programs and policies influence these behavioral parameters directly and indirectly, so the model could explore alternative policy strategies. While such a systems model of the segmented labor market, incorporating rich job-search and turnover behavior, allows many questions to be studied, it requires extensions in many directions. Structural changes in the product and labor markets that would facilitate expansion without inflation and that would improve the relative position of the competitively disadvantaged are urgently needed.

\section{Discussion}

Lawrence Klein and Edward Gramlich were interested in connecting the model in the paper with government policies that have an impact on the labor market. For example, unemployment insurance, welfare programs, 
and minimum wages could be fed into the model to provide some estimate of the effects of these policy variables.

Michael Wachter noted that the estimated lag in labor force participation is the same as the maximum duration of unemployment insurance benefits. He commented that covered workers cannot conveniently leave the labor force without losing their unemployment benefits. Smith thought such an effect unlikely because the labor force dropouts were mostly women and teenagers, and neither group is heavily covered by unemployment insurance.

Klein raised the issue of the implications of these results for social stability in the United States. How high did unemployment rates for specific demographic groups have to go before generating serious social unrest? Smith noted that for groups already experiencing high unemployment, such as youths and blacks, withdrawal from the labor force is a large part of the forecast response to poor job opportunities. This suggested "turned-off" workers who may have given up on lawful employment and become social problems as a result. Holt referred to studies showing that unemployment can lead to decreased labor force participation years into the future, possibly because of psychological scars inflicted by the original joblessness.

Franco Modigliani was skeptical of the substantial participation rate effects reported in the paper. He suspected that the "additional worker" effect of secondary workers entering the labor force when primary workers lose their jobs would counteract some of the "discouraged worker" effect. Arthur Okun and Gramlich cited Gramlich's evidence (BPEA, 2:1974) that while the wives of unemployed spouses do enter the labor force, the 85 percent of wives without unemployed spouses are more likely to leave the labor force because of high unemployment.

Christopher Sims questioned the finding that labor force participation rates for people over 60 rise slightly during periods of high unemployment. While noting that this result was questionable because sample sizes were small for this group, Holt and Smith offered a possible explanation for the phenomenon: as the unemployment rate rises, people who would ordinarily retire hold off that decision because of rising apprehensions about their retirement support during bad times.

George Perry compared Smith's estimates of cyclical effects in the labor market with his own findings (BPEA, 2:1972) that an increase in unemployment has an impact on employment that is twice as large as the impact upon labor force participation. Smith's simulation indicates an employ- 
ment effect four times as large as the labor force effect. Smith noted that the dynamic effect was temporary, and that after the adjustment process was complete, the sizes of the two effects were comparable to Perry's estimates.

Wachter questioned whether part of the coefficient estimated in the paper as unemployment effects might be attributable to real wage changes instead. In order to distinguish between the two effects, it would be necessary to include a relative wage term or a wage-price ratio as a regressor in the equations. Holt did not believe that including this new variable would significantly change any of the results because it moves so slowly over time, but agreed that it should be added. 